\title{
Analisis Minat Mahasiswa Mengakses Pesan-Pesan Dakwah Melalui Smartphone Pada Mahasiswa Jurusan Dakwah dan Komunikasi
}

\author{
Muhammad Aidil \\ Prodi BKI IAIN Parepare
}

PENDAHULUAN

Dakwah merupakan sebuah proses dalam menjadikan perilaku seseorang untuk menjalankan agama Islam sebagai agama rahmatan lil alamin dan harus didakwahkan kepada umat lainnya. Dakwah ini bertujuan dalam mengembalikan fitrah manusia dengan agamanya, dan menyadarkan manusia tentang perlunya bertauhid dan mau mengamalkan ajaran-ajaran Islam, serta berprilaku baik kepada sesamanya. Islam adalah agama dakwah, yang menyebarluaskan seluruh kebenarankebenaran dan mengajak semua orang yang belum memercayainya untuk percaya, menumbuhkan pengertian dan kesadaran dalam diri agar umat Islam mampu menjalani hidup yang sesuai dengan perintah-perintah yang dianggap sebagai tugas suci dan itu merupakan tugas setiap muslim. Dengan demikian setiap umat muslim berkewajiban untuk berdakwah.

Seperti dalam firman Allah surat Ali Imran/3:110.

Kamu adalah umat yang terbaik yang dilahirkan untuk manusia, menyuruh kepada yang ma'ruf, dan mencegah dari yang munkar, dan beriman kepada Allah. Sekiranya ahli kitab beriman, tentulah itu lebih baik bagi mereka, diantara mereka ada yang beriman, dan kebanyakan mereka adalah orangorang yang fasik.

Dakwah merupakan sebuah aktifitas yang sangat penting dalam Islam. Dengan dakwah Islam dapat tersebar dan diterima oleh seluruh umat manusia. Dalam kehidupan bermasyarakat, dakwah memiliki fungsi untuk menata kehidupan yang agamis dalam menuju terwujudnya masyarakat yang harmonis dan bahagia 
dunia akhirat. Ajaran Islam yang disiarkan atau disebarkan melalui dakwah dapat menyelamatkan seluruh umat manusia dan masyarakat pada umumnya dari hal-hal yang membawa pada sifat kehancuran itu sendiri. ${ }^{1}$

Salah satu sebagai misi rahmatan lil'alamin yang diajarkan dalam Islam ialah berdakwah dijalan Allah mengajak umat manusia dengan bijaksana serta dengan cara yang baik dan benar. Hal ini sesuai firman Allah dalam surat AnNahl/16: 125.

Artinya:

Serulah kepada jalan Tuhanmu dengan hikmah dan nasehat baik dan bertukar pikiran dengan cara yang lebih baik, sesungguhnya Tuhanmu lebih mengetahui siapa yang sesat dari jalan-Nya, dan dialah yang mengetahui siapa yang mendapat petunjuk.

Pengertian dakwah sebagaimana yang dipahami dalam surat an-Nahl ayat 125 mempunyai makna yang universal dan mendalam, begitu juga dengan berbagai pengertian yang telah dibaca tentang definisi dakwah. Jelas bahwa dakwah merupakan misi atau tugas agama yang luhur dan mulia karena merupakan suatu upaya dan usaha dalam merubah uamt manusia dari suatu kondisi yang kurang baik ke kondisi yang lebih baik.

Dakwah itu sebagai kegiatan untuk mengajak seseorang kepada kebaikan dan menjauhkan seseorang dari kegiatan keburukan. Dakwah juga merupakan upaya-upaya untuk menyeru, mengajak, mempersuasi dan memandu manusia ke arah yang benar dalam memahami dan menerima Islam sebagai agama yang syumul. Pelaksanaan kegiatan berdakwah ini adalah sesuatu yang sangat dianjurkan dan

\footnotetext{
${ }^{1}$ Venny Yunita, "Analisis Isi Pesan-Pesan Dakwah Pada Buku Percepatan Rezeki dalam 40 Hari dengan Otak Kanan" (Skripsi Sarjana; Jurusan Komunikasi Penyiaran Islam: Banda Aceh, 2018), h. 1-2.
} 
dimuliakan dalam agama Islam, dengan memposisikan pelaku-pelaku dakwah sebagai umat yang dimuliakan dalam pandangan Allah swt. ${ }^{2}$

Inilah antara lain tantangan berat dakwah di jagat maya. la tidak sesederhana menikmatinya ketika media telah menjadi barang rumah tangga biasa, tetapi sekaligus menjadi tantangan tersendiri kreativitas pelaku dakwah. Dakwah tidak lagi dilakukan hanya melalui pendektan-pendekatan konvensional dengan mengandalkan media lisan dari mimbar ke mimbar, tetapi membutuhkan proses rekayasa teknologi yang dapat membuka ruang interaksi yang lebih leluasa.

Secara sosiologis, penerapan teknologi informasi dan komunikasi dalam kehidupan itu dapat mengubah berbagai ragam interaksi masyarakat secara signifikan. Masyarakat dakwah kini bukan saja mereka yang berada di depan mata ataupun diatas mimbar saja, melainkan juga mereka yang secara bersama-sama ada diruang dunia maya. Media telah membawa individu memasuki ruang yang memungkinkan saling berinteraksi. Contohnya internet, yang kini telah membentuk ruang maya tempat saling menyapa secara interaktif yang kemudian kita kenal dengan istilah cyberspace.

Mungkin sulit dibayangkan sebelumnya jika seorang da'i menyampaikan pesan-pesan agama dapat berkomunikasi secara leluasa dan saling aktif dengan ratusan atau bahkan ribuan pendengar yang tersebar di bumi ini tanpa harus beranjak dari ruang kerja dirumahnya itu sendiri. Komunikasi itu berlangsung dinamis dengan bantuan fasilitas internet. Suasananya menjadi hidup dilengkapi

\footnotetext{
${ }^{2}$ Abdurrazaq, "Analisis Pesan Dakwah dalam Karya Sastra," (Studi atas Publikasi NovelNovel Islami Karya Habiburrahman El-Shirazy 19, no. 2, 2013), h. 206.
} 
tanya-jawab yang saling menjelaskan. Hasilnya pun dapat disimpan pada "tempat" khusus di ruang maya untuk dibuka dan dibaca kembali kapan saja diperlukan.

Karena itu, dalam menyampaikan pesan-pesan agama, seorang da'i tidak lagi harus menghadirkan masyarakat sebagai sasaran duduk di depan mata. Melalui media semua dapat menuliskan sebuah pesan itu dan menyebarkannya langsung hingga menemui para pembacanya dengan secara geografis tersebar di lokasi-lokasi yang hampir tidak terbatas. Melalui media eletronik ia dapat membuat rancangan sebuah sajian yang sarat baik dan bernilai untuk di dengar dan dilihat oleh pengguna internet. Atau dapat saja langsung berinteraksi dengan melalui akat bantu media seperti media sosial, blog, dan semacamnya, mengunjungi rumah-rumah yang telah dilengkapi fasilitas internet, atau bahkan menemani individu-individu dimanapun yang kebetulan dilengkapi dengan fasilitas media yang saling aktif seperti itu dalan genggaman tangannya.

Seperti itulah pilihan-pilihan dakwah di era cyberspace ini yang sulit ditawar-tawar lagi. Dakwah kemudian dihadapkan pada pilihan-pilihan metodologis yang mungkin sebelumnya tidak pernah terbayangkan. Dakwah berjalan diantara rentang peluang hidup dan mati. Jika dakwah ingin tetap survive di tengah arus perubahan yang dimotori kekuatan efek teknologi informasi dan komunikasi, ke depan perlu terus melakukan berbagai pembaruan, meredefinisi konsep-konsep atau merekonseptualisasi fakta-fakta sekaligus merekonstruksi realitas serta gagasan dan gerakan dakwah sesuai perubahan.

Dengan demikian, kedepan diperlukan pola-pola sebagai penyampaian dakwah islam yang kini tidak lagi untuk menuntut kehadiran masyarakat secara langsung. Dengan salah satu solusinya adalah dakwah disampaikan melalui bantuan 
media. Medialah kemudian yang akan mengantarkan pesan-pesan islami hingga menyentuh para jamaah dalam beragam nuansa dan suasana. Dengan begitu, dakwah bisa berjalan terus meskipun kesempatan mereka telah disita seluruhnya. Dakwah yang disampaikan melalui media akan tetap datang mengunjungi mereka yang sedang istirahat di rumah masing-masing. Mereka masih tetap bisa menikmati dan mengakses sajian dakwah islam, tanpa harus meninggalkan pertemuan keluarga. $^{3}$

Pengaruh teknologi pada zaman modern ini sangat berpengaruh semua kalangan baik itu kalangan anak-anak, remaja, orang dewasa, maupun orang tua begitu halnya pada bidang komunikasi. Terlebih lagi alat komunikasi yang serba canggih pada saat ini, dengan menghadirkan sebuah hasil yang berupa peralatan elektronik dan bahan perangkat lunak yang disajikan yang mampu mempengaruhi seluruh sector kehidupan termasuk pendidikan. Hal ini berarti bahwa teknologi sangat berperan penting dalam kehidupan manusia, terutama dalam hal pencarian informasi-informasi serta memungkinkan bagi pemakainya untuk berkomunikasi secara cepat dan aman. Salah satu wujud perkembangan yang modern teknologi informasi dan komunikasi tersebut adalah Smartphone.

Teknologi Smartphone merupakan sebuah alat yang canggih yang bisa dimiliki oleh siapa saja baik itu anak-anak, remaja, orang dewasa maupun orang tua. Hal ini disebabkan karena Smartphone bisa digunakan dimana saja dan bisa dibawa kemana saja, berbeda dengan komputer ataupun laptop yang ukurannya agak lebih besar.

\footnotetext{
${ }^{3}$ Prof. Dr. Asep Saeful Muhtadi, Komunikasi Dakwah Teori, Pendekatan, dan Aplikasi. (Bandung: Simbiosa Rekatama Media, 2012), h. 4-5.
} 
Smartphone memiliki kelebihan utamanya yakni pengaksesan internet yang begitu cepat dan canggih, kemudian menunjang aktivitas orang dalam melakukan interaksi sosial melalui fitur-fitur media sosial, seperti yang sekarang digunakan ini adalah media sosial Facebook, BBM, WhatsApp, Instagram, Blog dan Youtube. ${ }^{4}$

Melihat fenomena ini, dimana zaman sekarang atau dibilang zaman now bisa dikatakan zamannya teknologi canggih seperti halnya teknologi smartphone yang digunakan oleh semua orang baik itu anak-anak SD, SMP, SMA, maupun mahasiswa. Dilihat penggunaan smartphone di IAIN Parepare ini, sebagian mahasiswa lebih banyak hanya update status, main game, chattingan bersama teman maupun pacar, foto selfie dan tidak terlalu berminat untuk mengakses pesanpesan dakwah melalui smartphone mereka. Terkadang ketika ada pesan-pesan dakwah yang disebarkan oleh teman-temannya baik itu berupa video dakwah maupun dakwah tertulis mereka hanya mengabaikan atau tidak melihat dan tidak membaca pesan-pesan dakwah tersebut dan ada juga sebagian mahasiswa suka mengakses dakwah-dakwah melalui smartphone baik itu akses dari blog, whatsapp, instagram, facebook, BBM, dan youtube.

Berdasarkan permasalahan-permasalahan yang terjadi yang disebutkan dilatar belakang, membuat peneliti tertarik untuk melakukan penelitian dengan tema sentral yaitu "Analisis Minat Mahasiswa Mengakses Pesan-Pesan Dakwah Melalui Smartphone pada Jurusan Dakwah dan Komunikasi".

\footnotetext{
${ }^{4}$ Rahayu Suci Miranda, "Pemanfaatan Smartphone dalam Meningkatkan Kinerja Jurnalis Kampus (Studi Pada Unit Kegiatan Pers Mahasiswa SumberPost)" (Skripsi Sarjana; Jurusan Komunikasi Penyiaran Islam: Banda Aceh, 2018), h. 1-2.
} 


\section{REFERENCES}

(1) Abdullah, B. (2016) 'KONSTITUSI PENDIDIKAN ISLAM DALAM MEMBANGUN MASYARAKAT MADANI', KURIOSITAS: Media Komunikasi Sosial Keagamaan, 9(2), pp. 79-86.

(2) Ahdar, A. (2017) 'TINJAUAN KRITIS DAN MENYELURUH TERHADAP FUNDAMENTALISME DAN RADIKALISME ISLAM MASA KINI', KURIOSITAS: Media Komunikasi Sosial dan Keagamaan, 10(1), pp. 19-36.

(3) Al-Amri, L. and Haramain, M. (2017) 'AKULTURASI ISLAM DALAM BUDAYA LOKAL', KURIOSITAS, 10(2), pp. 87-100.

(4) Al-Khalidy, Shalah 'Abd al-Fattah. 2000. Ma'a Qishash al-Sabikin fiy al-Qur'an, ditrerjemahkan oleh Setiawan Budi Utomo dengan judul Kisah-kisah Al-Qur'an: Pelajaran dari Orang-orang Dahulu. Cet. I; Jakarta: Gema Insani Press.

(5) Al-Maragiy, Ahmad Mushthafa.Tafsiral-Maragiy. Bairut: Dar al-Fikr, t.th.

(6) Al-Maududi, Abul A'la. 1986. Pengertian Agama, Ibadah dan Ketuhanan Yang Maha Esa dalam Al-Qur'an, diterjemahkan oleh Mahyuddin Syaf tanpa menyebut judul aslinya. Cet. I; Bandung: Sinar Baru.

(7) Al-Qaththan, Manna'. Mabahif fiy 'Ulum al-Qur’an.Bairut : Muassasah al- Risalah, t.th.

(8) Al-Qurthubiy, Abiy 'Abdillah Muhammad ibn Ahmad al-Anshariy.Al-Jami' li Ahkam al-Qur'an. Bairut: Dar al-Fikr li al-Thaba'ah wa al-Nasyr wa al-Tauzi', t.th.

(9) Al-Shabuniy, Muhammad 'Aliy. Shafwah al-Tafasir.Kairo: Dar al-Fikr, t.th.

(10) Anwar, A. (2016) 'KONTRIBUSI KELUARGA TERHADAP PEMBENTUKAN KARAKTER ANAK (Studi Perspektif Modal Sosial di Kota Parepare)', KURIOSITAS, 9(1), pp. 5765.

(11) Arifin, Bey.Rangkaian Cerita dalam Al-Qur'an.Cet.XVII; Bandung: PT. Alma'arif, t.th.

(12) Azis, A. and Jufri, M. (2017) 'IMPLEMENTASI NILAI-NILAI AJARAN TAU LOTANG TERHADAP MASYARAKAT LOKAL WATTANG BACUKIKI KOTA PAREPARE', KURIOSITAS: Media Komunikasi Sosial dan Keagamaan, 10(2), pp. 23-41.

(13) Azis, S. A., Herdah, H. and Jufri, M. (2016) 'IMPLEMENTASI MODEL PEMBELAJARAN KOOPERATIF MAHASISWA PROGRAM STUDI BAHASA ARAB STAIN PAREPARE (Studi Pengembangan Pembelajaran Mata Kuliah Serumpun)', KURIOSITAS, 9(1), pp. 81102.

(14) Azra, Azyumardi (ed.). 1999. Sejarah dan ‘Ulum al-Qur’an. Cet.I; Jakarta: Pustaka Firdaus.

(15) Bisri, A. Mustofa. 2000. "Taat, Ibadah, dan Taqarrub (Bebas Menyendiri dengan Diri Sendiri)", dalam Nurcholish Madjid, et al., Puasa: Titian Menuju Rayyan.Cet. I;

Yogyakarta: Pustaka Pelajar.

(16) Budiman, B., Musyarif, M. and Firman, F. (2016) 'IDEOLOGI BULETIN DAKWAH ALISLAM DALAM KAJIAN WACANA KRITIS', KURIOSITAS, 9(1), pp. 21-34. 
(17) Chazawi,Adami. 2002. Pelajaran Hukum Pidana Bagian Ketiga.Cet. I; Jakarta: PT Raja Grafindo Persada.

(18) Hamka. 1992. Tafsir al-Azhar. Jakarta: PT Pustaka Panjimas.

(19) Haramain, M. (2012) 'Pemikiran dan Gerakan Dakwah Tuan Guru M. Zainuddin Abdul Madjid di Lombok NTB'. Makassar: Universitas Islam Negeri Alauddin Makassar.

(20) Haramain, M. (2016) 'al-Wasathiyyah wa Atsaruha fi al-da'wah al-Islamiyyah: Dirasah Lugawiyyah Manhajiyyah', Langkawi: Journal of The Association for Arabic and English, 2(1), pp. 83-100.

(21) Haramain, M. (2017) 'DAKWAH DALAM ARUS GLOBALISASI MEDIA: PELUANG DAN TANTANGAN', KOMUNIDA: MEDIA KOMUNIKASI DAN DAKWAH, 7(1), pp. 60-73.

(22) Haramain, M. (2019) Prinsip-prinsip Komunikasi dalam al-Qur'an. Parepare: IAIN Parepare Nusantara Press.

(23) Hidayat, W. (2016) 'PERSEPSI SISWA SMA KOTA PAREPARE TENTANG STAIN PAREPARE', KURIOSITAS: Media Komunikasi Sosial Keagamaan, 9(1), pp. 49-56.

(24) Ilham, M. I. M. (2017) 'HERMENEUTIKA AL-QUR'AN', KURIOSITAS: Media Komunikasi Sosial dan Keagamaan, 10(2), pp. 101-119.

(25) Ipandang, I. (2017) 'FILSAFAT AKHLAK DALAM KONTEKS PEMIKIRAN ETIKA MODERN DAN MISTISISME ISLAM SERTA KEMANUSIAAN', KURIOSITAS: Media Komunikasi Sosial dan Keagamaan, 10(1), pp. 1-18.

(26) Juddah, A. B. (2015) 'ANALITIS SINTETIK TERHADAP STRATEGI PEMBELAJARAN ANDRAGOGI BERPERSPEKTIF KEMANDIRIAN DOSEN DALAM PEMBELAJARAN', Kuriositas: Media Komunikasi Sosial dan Keagamaan, 8(2), pp. 41-45.

(27) Khairul, K. and Haramain, M. (2018) 'Aplikasi Digital Risalah Ilmu Tajwid dalam Meningkatkan Kemampuan Baca Al Qur'an', KURIOSITAS: Media Komunikasi Sosial dan Keagamaan, 11(2), pp. 145-157.

(28) Mahfud,Sahal. 2000. "Ibadah Sosial Tentukan Kualitas Iman", dalam Nurcholish Madjid, et al., Puasa: Titian Menuju Rayyan.Cet. I; Yogyakarta: Pustaka Pelajar.

(29) Marpaung, Leden. 1991. Unsur-unsur Perbuatan yang Dapat Dihukum (Delik). Cet. I; Jakarta: Sinar Grafika.

(30) Muammar, M. and Suhartina, S. (2018) 'Media Pembelajaran Berbasis Teknologi Informasi Dalam Meningkatkan Minat Belajar Akidah Akhlak', KURIOSITAS: Media Komunikasi Sosial dan Keagamaan, 11(2), pp. 176-188.

(31) Mulianah, S. and Hidayat, W. (2016) 'PENGEMBANGAN TES BERBASIS KOMPUTER', KURIOSITAS: Media Komunikasi Sosial dan Keagamaan, 9(2), pp. 27-43.

(32) Muliati, M. (2016) 'PENGARUH PAHAM KEAGAMAAN TERHADAP ETOS KERJA PEDAGANG PASAR SENTRAL KABUPATEN PINRANG', KURIOSITAS: Media Komunikasi Sosial Keagamaan, 9(2), pp. 101-115.

(33) Munawwir, Ahmad Warson.Al-Munawwir: Kamus Arab-Indonesia.Yogyakarta: Pondok Pesantren al-Munawwir, t.th.

(34) Quthub, Sayyid. 1971. Fiy “ilal al-Qur'an. Cet. VII; Bairut: Mazidah wa Manqahat. 
(35) Rachman, Luthfi. 2000. "Nilai Ikhlas dalam Puasa Ramadhan", dalam Nurcholish Madjid, et al.Puasa: Titian Menuju Rayyan.Cet. I; Yogyakarta: Pustaka Pelajar.

(36) Rahmawati, R., Wahidin, W. and Aris, A. (2015) 'MATERI FIQH IBADAH DAN IMPLEMENTASINYA BAGI MAHASISWA JURUSAN SYARIAH STAIN PAREPARE', KURIOSITAS: Media Komunikasi Sosial Keagamaan, 8(1), pp. 71-86.

(37) Shihab,M. Quraish. 1992. Membumikan Al-Qur'an: Fungsi dan Peran Wahyu dalam Kerhidupan Umat.Bandung: Mizan.

(38) Sunubi, A. H., Dalle, A. and Maghdalena, M. (2016) ‘ENGLISH TEACHER INSTRUCTION IN GIVING MATERIAL BY USING CODE SWITCHING AND CODE MIXING IN SMU NEG. 2 PAREPARE', KURIOSITAS, 9(1), pp. 35-47.

(39) Tanwir, T. and Said, H. (2018) 'Inovasi Pembelajaran Guru Pendidikan Agama Islam Berbasis Teknologi Informasi', KURIOSITAS: Media Komunikasi Sosial dan Keagamaan, 11(2), pp. 189-210.

(40) Ulum, A. C. and Haramain, M. (2017) 'EKSISTENSI DAKWAH DALAM MERESPON PLURALISME', KOMUNIDA: MEDIA KOMUNIKASI DAN DAKWAH, 7(2), pp. 124-138. 